\title{
YELLOW PASSION-FRUIT IRRIGATED IN DIFERENT CROPPING SYSTEMS ${ }^{1}$
}

\section{SAMUEL FERREIRA DE SOUZA² \& VALTEMIR GONÇALVES RIBEIRO ${ }^{3}$}

\begin{abstract}
With this study, the objective was to determine the most economic management of irrigation water applied at different levels in the culture of passion fruit grown in conventional system and in polyethylene bags. The experiment was conducted in the city of Remanso, state of Bahia, Brazil. The experimental set-up was a randomized block design in a factorial design 2 (conventional system, and polyethylene bags of 100 L) x 5 (irrigation levels: $100 \%, 80 \%, 60 \%, 40 \%$ and $20 \%$ an irrigation management at field capacity) with four replications and four plants per plot. The treatments began 30 days after transplanting the seedlings to the field, and the analyzed variables were: plant height, stem diameter, leaf area and number of tertiary branches, of flower buds and fruits per plant. The data were interpreted by means of analyses of variance (test F) and means were compared by Tukey test at 5\% probability of error. It was found that the yellow passion fruit got greater agronomic performance when grown in polyethylene bags, with irrigation management at $80 \%$ field capacity.
\end{abstract}

Index terms: Passiflora edulis; water management; plant growth.

\section{MARACUJAZEIRO-AMARELO IRRIGADO EM DIFERENTES SISTEMAS DE CULTIVO}

RESUMO - Com este estudo, o objetivo foi determinar o manejo econômico de água de irrigação aplicada em diferentes lâminas na cultura do Maracujazeiro-amarelo cultivado em sistema convencional e em bolsas de polietileno. O experimento foi realizado numa propriedade do Município de Remanso-BA, em delineamento de blocos casualizados em esquema fatorial 2 (sistema convencional e em bolsas de polietileno de 100 L) x 5 (lâminas de irrigação: $100 \%, 80 \%, 60 \%, 40 \%$ e $20 \%$ da capacidade de campo), com quatro repetições, e quatro plantas por cada repetição, sendo que a aplicação dos tratamentos iniciou-se após 30 dias do transplantio das mudas ao campo. As variáveis analisadas foram: altura de planta, diâmetro do colo, área foliar e número de ramos terciários e de botões florais e de frutos por planta. Os dados foram submetidos à análise de Variância (teste F) e as médias comparadas entre si pelo teste Tukey, a $5 \%$ de probabilidade de erro. Verificou-se que o Maracujazeiro-amarelo obteve maior desempenho agronômico quando cultivado em bolsas de polietileno, disponibilizando-se $80 \%$ da capacidade de campo.

Termos para indexação: Passiflora edulis; manejo de água; crescimento de planta.

${ }^{1}$ (Trabalho 045-15). Recebido em: 16-01-2015. Aceito para publicação em: 04-08-2015.

${ }^{2}$ Agricultural Engineer, in the Masterss graduate program of Irrigated Horticulture-Crop Production, UNEB, Juazeiro-BA. E-mail: samu-remanso@hotmail.com.

${ }^{3}$ Agricultural Engineer, Professor Dr. of the University of the State of Bahia, graduate program in Irrigated Horticulture, Juazeiro-BA. E-mail: valtemir.ribeiro@gmail.com 


\section{INTRODUCTION}

Passion Fruit is the popular name given to several species of the genus Passiflora, it presents great diversity of edaphoclimatic conditions and different production cycles, starting the production from the sixth month after planting, which provides producers with revenues distributed by most of the year. There are 500 species distributed in regions of tropical and subtropical climate of the World, Brazil is the largest producer with more than 79 species in an area of 62.000 ha, especially the northeast and southeast regions as the largest producers of the fruit. (CAZARIN et al., 2014; IBGE, 2012; MELETTI, 2011; ZERAIK et al., 2010).

Although the passion fruit is relatively drought tolerant, in the event of prolonged water stress periods the plat growth is impaired and in rainfed conditions it develops satisfactorily if it is provided with a rainfall of 800 to $1,750 \mathrm{~mm}$ well distributed during the year (LAREDO, 2013). Thus, for the Brazilian semi-arid regions where the rains occur in a few periods (annual average of $400 \mathrm{~mm}$ ), causing water shortage in some months, the use of irrigation is essential to ensure good production and fruit quality; the region is characterized by conditions of high evapotranspiration demand, the higher temperature values occur in the months from October to December, and the rainy season is limited to the months from January to April (EMBRAPA, 2012).

According to Bernardo (2009), when starting an irrigation project it is important to remember the increase of production and the rational use of water, in order to minimize the soil structure deterioration and nutrient losses, and to prevent excessive loss of water through the percolation to the deeper layers of the soil profile. Therefore, the cultivation of passion fruit in polyethylene bags that can increase the use of water is suggested because the loss of water in the root system operational environment only happens by evapotranspiration, increasing the irrigation schedule time or decreasing the applied levels for irrigation without affecting production. Carvalho et al. (2010) studying the development and productivity of yellow passion fruit under different irrigation levels in protected and natural environment, observed that business productivity did not suffer effect of water stress in the soil, with an average yield of $72.02 \mathrm{tha}$ ${ }^{1}$, higher than the national average (13.395 $\left.\mathrm{kg} \mathrm{ha}^{-1}\right)$; and, when Araújo et al. (2012) handled the Yellow Passion Fruit in Pentecoste (CE), providing 50\% of irrigation required in the evening period and $50 \%$ in the morning, they found that the total water level spent during the stages of vegetative development to production (cycle of 180 days) was close to the lower limit of the recommended range for the crop, resulting in greater productivity for the crop.

Thus, the development of more researches that aim planning irrigations to maximize the yields per unit of water is necessary mainly in semi-arid regions where water is a limiting factor. Based on the above, this study aimed to determine the economic management of irrigation water applied at different levels in the culture of Yellow Passion Fruit in conventional management system and polyethylene bags.

\section{MATERIAL AND METHODS}

The experiment was conducted in the municipality of Remanso - BA (coordinates: 09॰37'47.1'S; 4204'56.7' W, altitude: $399 \mathrm{~m}$ ), the Lower Basin of the São Francisco Valley, left bank of the Sobradinho Lake, in a soil classified as Regolithic Neossol (SANTOS et al., 2012), from May, $1^{\text {st }}$ to June $26^{\text {th }}$ of 2013.The region's climate, according to Köeppen classification, is classified as BSwh, hot semi-arid climate with average rainfall of $718 \mathrm{~mm} /$ year and average temperatures above $18^{\circ} \mathrm{C}$.

The seedlings were grown in the nursery of the Department of Technology and Social Sciences of the University of the State of Bahia - DTSS/USB, and 80 days after emergence they were transplanted into planting holes prepared in spacing of $2.5 \mathrm{~m} \mathrm{x}$ $4.0 \mathrm{~m}, 50 \times 50 \times 50 \mathrm{~cm}$ for the conventional system of planting and $50 \times 50 \times 60 \mathrm{~cm}$ for the cultivation system in polyethylene bags.

The espaliers were built with wood; stakes with space of 8 meters with a taut wire at a height of $1.8 \mathrm{~m}$ in area previously prepared by manual hoeing and ground leveling. The physical and chemical characterization of the soil was held in the Soil, Water and Limestone Analysis Laboratory (SWLAL) of the University of the State of Bahia, campus III, Juazeiro (Table 1).

As for the fertilization, it was applied in the foundation the minimum dose of phosphorus recommended for the crop $(20 \mathrm{Kg} / \mathrm{ha})$ in Super Simple formulation containing about $21 \mathrm{~kg}$ of calcium, $+50 \mathrm{~kg} / \mathrm{ha}$ of nitrogen in urea form, and weekly fertilizations via fertigation, being applied about $100 \mathrm{~g}$ of urea per plant, as recommended by the MANUAL DE ADUBAÇÃO E CALAGEM PARA O ESTADO DA BAHIA (1989) ("Fertilizing and Liming Manual of the State of Bahia") (Table 2), besides foliar fertilization with calcium, boron, magnesium and sulfur; potassium fertilization was 
not necessary due to its high content found in the soil.

The seedlings were transplanted on May $1^{\text {st }}$, 2013 in order to be managed under two types of cultivation: in polyethylene bags with a capacity of 100 liters and in conventional system. 30 days after transplanting, the seedlings of each cropping system were subjected to the following treatments with different irrigation levels: $\mathrm{T} 1=100 \%, \mathrm{~T} 2=80 \%, \mathrm{~T} 3$ $=60 \%, \mathrm{~T} 4=40 \%$ and $\mathrm{T} 5=20 \%$ of the field capacity.

For the irrigation management, we established the fixed irrigation turn with variable level (Table 3 ), determining the water level replacement from the reading in tensiometers, using a Puncture Digital Tensiometer (PDT), with sensitivity of 0.1 $\mathrm{kPa}$, always based on the water retention in soil characteristic curve (Figure 1). The water retention in the soil curve was obtained from 0 to $40 \mathrm{~cm}$ of depth, using for this purpose wooden box without a bottom with dimensions of $1 \mathrm{~m} \times 1 \mathrm{~m}$ buried to a depth of 40 $\mathrm{cm}$ and in polyethylene bags with a volume of 100 liters (BANDEIRA et al., 2013). The readings were carried out in two moments: at $8 \mathrm{~h} 00$ and $16 \mathrm{~h} 00$, the levels being recovered daily through irrigation drip with gauge pressure value of $1 \mathrm{~kg} / \mathrm{cm}^{2}$ and flow of $2.1 \mathrm{~L} \mathrm{~h}^{-1}$ in each dripper.

For each treatment, two batteries of tensiometers tubes were used, which were placed on the soil of the experimental area with the conventional cultivation system, each being composed of three tensiometric tubes installed on wet ground range at depths of 20 and $40 \mathrm{~cm}, 30 \mathrm{~cm}$ away from the plants, spaced apart by $10 \mathrm{~cm}$.

In order to relate moisture to weight basis, with moisture to volume basis, undisturbed soil samples were collected to establish the soil density in the depths of 20 and $40 \mathrm{~cm}$. In order to ensure similar conditions of water storage, the soil density in the containers were established by the relationship between mass and volume of the soil (BERNARDO, 2009).

Two water samples were collected and taken to the laboratory of water analysis of SENAI, where the total chemical analysis in order to verify the quality of it for irrigation purposes was performed (Table 4). Sodium Adsorption Ratio (SAR) was calculated and it showed that the water used for irrigation contains a value equal to 0.071 that is a SAR considered low, according to Cordeiro (2001).

Some crop treatments were carried out over the conducting of the experiment, such as manually preparation of the soil and pruning to remove the side branches produced before the plant reaches $1.8 \mathrm{~m}$ in height, pruning of apical branches to force the growth of secondary branches, besides pruning of tertiary branches and the staking of the plant was made with ribbons. Two lateral branches as productive branches in the form of curtains were conducted. The only plague found during the execution of the study was the "Caterpillar of the passion fruit leaves", which was controlled by manual scavenging.

The variables analyzed were: plant height (at 45 and 75 days after the transplanting - DAT), stem diameter (45, 75 and 105 DAT), leaf area and number of tertiary branches(105 DAT), number of flower buds (105 and 120 DAT) and number of fruits per plant $(120,150,180$ and 210 DAT). The plant height was measured with a graduated measuring tape and the stem diameter measured with a digital pachymeter.

The determination of secondary and tertiary branches emission was carried out by visual observation and counting. The determination of leaf area was carried out by collecting from the fifth leaf from the tertiary branches, in a total of 10 leaves per plant, where they were photographed and processed in ImageTool ${ }^{\circledR}$ software, and the production and productivity were determined by weighing the fruits and by fruit total per plant in the area.

The experiment was conducted in a randomized block design in a factorial design 2 (conventional system, and polyethylene bags of 100 L) x 5 (irrigation levels: $100 \%, 80 \%, 60 \%, 40 \%$ and $20 \%$ an irrigation management at field capacity) with four replications and four plants per plot, and the treatment with irrigation levels was initiated 30 days after transplanting the seedlings to the field. The data were submitted to analysis of Variance (F test) and the Turkey Test compared the averages at $5 \%$ error probability.

During the experiment, we did not record significant rainfall, thus there was no interference on the need for irrigation and too long intervals between one watering and another.

\section{RESULTS AND DISCUSSION}

Data concerning the evaluations of the Yellow Passion Fruit height at 45 DAT under different irrigation levels for 15 days under the two proposed cultivation systems are showed at table 5 . There is difference between the cultivation systems, especially for the treatment with application of $80 \%$ of the irrigation levels, and the conventional culture showed inferior results, the average plant size is $44.25 \mathrm{~cm}$, differing significantly from the average of the cultivation system in polyethylene bag that reached the height of $92.50 \mathrm{~cm}$ for the same irrigated level. 
There was no significant difference for the irrigation level factor. This might happened because of the short time between the treatments and the analysis of the results, since the different irrigation levels were being applied only for 15 days. Although the literature indicates that the passion fruit responds well to water application, it is understood that the plant would need a continuous period bigger than 15 days of treatment exposure with irrigation levels for significant gains to be expressed in their dimensions. Araújo et al. (2012) verified the total consumption of water required by the Yellow Passion Fruit calculated from the evaporation data from a Class A Tank was $956.60 \mathrm{~mm}$.

We found that there was high interaction between the factors in the 75 DAT, the plant height values were statistically different and growing in bags positively influenced the growth of plants, while the irrigation levels interfered negatively in plants grown in bags as irrigations were reduced, it was more visible in treatments with $40 \%(93 \mathrm{~cm})$ and $20 \%$ level $(76.25 \mathrm{~cm}$ ) (Table 5). However, in the factors interaction, we observed that growing Yellow Passion Fruit in plastic bag had more efficiency in the initial growth, especially with the recovery of $80 \%$ of field capacity, where 45 and 75 DAT showed plants average size of $92.50 \mathrm{~cm}$ and $186.00 \mathrm{~cm}$. Carvalho et al. (2010) concluded that more water tension in the soil negatively affects the growth of plants when they cultivated passion fruit under different stresses in natural and protected system. This happens due to a bigger expenditure of energy by the plant in search of water, and the higher water pressure is directly linked to its lowest substance in the soil. The low water intake by the plant reduces the evapotranspiration, delays phenological phases and results in lower productivity (TAIZ; ZEIGER, 2012).

For the variable stem diameter, we observed that in 45 DAT, the plants performance was similar. After 75 days of the plants being exposed to 45 days of different irrigation levels, the treatment with $80 \%$ application in conventional system provided $8 \mathrm{~mm}$ average, below the treatment average with $100 \%$ level $(12 \mathrm{~mm})$ in the same cultivation system, while the best average $(13.5 \mathrm{~mm})$ was the parcel that was receiving $80 \%$ of irrigation level cultivated in polyethylene bags (Table 6).

At 105 days of the transplanting, there was no interaction between the factors cultivation system and irrigation level for the variable stem diameter of the plants (Table 6), while the two cultivation systems obtained similar averages, not statistically different from each other. For the water factor, at the 105 days, the treatment with application of $40 \%$ water showed lower values of stem diameter in the cultivation systems (conventional and bags), with average values of the stem diameter at 14.75 and $15.75 \mathrm{~mm}$, respectively. In general, plants cultivated in plastic bags with 100 liters volume showed different performance from the conventional system for the variable evaluated: plant height and stem diameter at 45 and 75 DAT.

For the emission of tertiary branches variable, evaluated at 105 days after the transplanting, there was an interaction between de two factors, and the parcel cultivated in plastic bags was higher than the conventional cultivation and these showed lower branches number when the irrigation levels were reduced (40 and $20 \%$ ), in other words, opposite result to the one of the conventional system that showed lower averages in the treatments with higher application of irrigation levels ( 80 and $100 \%$ ) (Table 7). This may be related to the fact plants that received more water in an environment with more root exploration tend to have a plant development in height, occurring a lower lateral growth due to a sharp pronouncement of apical dominance of the branches.

There was also highlight for the treatment with application of irrigation levels $20 \%$ cultivated in conventional system (with four branches per plant). However, the factors benefited the plats cultivated in bags with replacement of $80 \%$ of field capacity, showing better interaction with the number of tertiary branches per plant (8.25).

Even at 105 days, we observed the presence of reproductive structures (floral buds) in some plants of both cultivation systems (Table 8). Taiz and Zeiger (2012) mention the beginning of reproductive phase in certain species only occur when the plant has specific number of leaves so there is transmission or synthesis of floral stimulus to the apex, and the day length and the air temperature are considered the most important environmental factors for the control of flowering, according to these authors. However, many species of Passiflora have different flowering behavior during the year, and the Yellow Passion Fruit is considered a "long days" plant and it needs 12 hours of light to flourish, on the other hand, in Jaboticabal (SP), the wild specie Passiflora Setacea D.C. is considered a "short days" plant produced a higher number of flowers in July and August (ATAÍDE et al., 2012).

In the evaluations performed during the fruit production until the 210 days there was no significant interaction between the studied factors in relation to the fruit number and weight variables, but analyzing individually the factors we found that plants cultivated in conventional way presented fruit with 
a higher average weight, while the cultivation bags had a larger number of fruit per plant (Table 8 ) and reached an average of 27 fruits per plant, while the fruit average for the conventional system was 19.75 fruits per plant. This may be associated to a larger drain source existing in the plant, because the larger number of fruit increases competition between them, reducing their size and weight; agreeing with the results of Hafle et al. (2009) which the decrease in the number of fruits allowed the larger size and weight of the remaining fruits.

Even the Passion Fruit plants of the cultivation system in bags had fruits with lower weight (209.9 g), comparing to the conventional system ( $240.1 \mathrm{~g})$, the cultivation in bags was more favorable because this cultivation type showed higher productivity and by 210 days of the first year of cultivation they had already reached a production of $5,667 \mathrm{~kg} /$ ha, while the conventional system had presented $4,740 \mathrm{~kg} / \mathrm{ha}$. Probably, the best results are due to more suitable conditions for cultivation caused by the physical improvement of the soil environment, resulting in greater availability of nutrients for plants, higher microbial activity, in addition, cultivation bags can provide the conservation of moisture and soil temperature.

In the evaluations of irrigation levels (Table 9), we observed that the treatment with $80 \%$ of application showed the highest average in the accumulation of the fruit number per plant and worst result were from the treatments remained with field capacity of $40 \%$ and $60 \%$, with average values of 17.62 and 18.12 fruits per plants, respectively.

When Araújo et al. (2012) were evaluating the effect of irrigation fractioning in different application times on yield and quality of yellow passion fruit, they observed that the higher number of fruits (74 fruits/plant) was obtained with the application of $100 \%$ of irrigation levels required by the crop, which indicates that a proper irrigation management can mitigate the evaporative effects and likely to increase productivity, according to Bernardo (2009). On the other hand, when Carvalho et al. (2010) studied the development and productivity of the Yellow Passion Fruit irrigated under different levels, in protected and natural environment, they concluded that the irrigation under tensions of until $60 \mathrm{kPa}$, in both environments, do not affect significantly the total commercial productions and the stem diameter, however, the water pressure affected the plants growth.

In relation to the leaf area, although it was not submitted to average test for treatments with the irrigation levels (Table 10), we observed that as the irrigation levels were reduced, the dimensions of the
Yellow Passion Fruit leaf area decreased; this effect can be verified in both cultivation systems, and the cultivation in bags showed a better balance between the values of the treatments.

Suassuna (2010) studying the development and photochemical efficiency in passion fruit hybrid seedlings under irrigation levels, also observed an increase in the leaf area caused by higher availability of water, which improves the absorption of solar radiation. According to Laredo (2013), the passion fruit needs large amount of water for a full success in the fruit production, and in conditions of poor availability of water the plants show a decrease in leaf growth, flower production, fruit size and volume of pulp produced.

The Yellow Passion Fruit is susceptible to various diseases, among which stands out the premature death of plants manifested and quickly decimates between the plants when they go into production, this disease is caused by soil fungi (Fusarium oxysporum f. passiflorae, Fusarium solani, Phytophthora spp), by nematodes and also by bacteria, such as Xanthomonas axonopodis pv. Passiflorae (CAVICHIOLI et al., 2014; CAVICHIOLI et al., 2011a, 2011b; NASSER et al., 2011); therefore, the attack of this disease in the semi-arid of the State of Bahia, where the rains happen at certain times of the year, can be minimized through a proper irrigation management, and in polyethylene bags with disinfected soil. 
TABLE 1- Physical and chemical characteristics of the soil used for the cultivation of Yellow Passion Fruit (Passiflora edulis Sims f. Flavicarpa Deg.) in Juazeiro-BA, 2014.

\begin{tabular}{lc}
\hline Parameters & Values \\
\hline Soil density $\left(\mathrm{g} / \mathrm{cm}^{3}\right)$ & 1.50 \\
$\mathrm{pH}\left(\mathrm{H}_{2} \mathrm{O}\right)$ & 5.52 \\
E.C. Sat. Ext. $(\mathrm{ds} / \mathrm{m})$ & 0.52 \\
Phosphorus $\left(\mathrm{mg} / \mathrm{dm}^{3}\right)$ & 37.0 \\
Calcium $\left(\mathrm{cmolc} / \mathrm{dm}^{3}\right.$ of TSDA) & 2.04 \\
Magnesium $\left(\mathrm{cmolc} / \mathrm{dm}^{3}\right.$ of TSDA) & 0.44 \\
Potassium $\left(\mathrm{cmolc} / \mathrm{dm}^{3}\right.$ of TSDA) & 0.82 \\
Sodium $\left(\mathrm{cmolc} / \mathrm{dm}^{3}\right.$ of TSDA) & 0.04 \\
Sum of base $\left(\mathrm{cmolc} / \mathrm{dm}^{3}\right.$ of TSDA) & 3.34 \\
Hydrogen + aluminum $\left(\mathrm{cmolc} / \mathrm{dm}^{3}\right.$ of TSDA) & 3.13 \\
CEC (cmolc/dm of TSDA) $^{3}$ Bases saturation $(\%)$ & 6.47 \\
P.E.S. & 51.62 \\
\hline
\end{tabular}

TABLE 2- Fertilizer recommendation for the passion fruit crop (Passiflora edulis Sims. f. Flavicarpa Deg.), from the soil analysis. Juazeiro-BA, 2014.

\begin{tabular}{ccc}
\hline Nutrient & Plantation (kg/ha) & $\mathbf{1}^{\text {st }}$ year (kg/ha) \\
\hline Nitrogen & 50 & 80 \\
Phosphorus in the soil - ppm & & 60 \\
Until 6 & 40 & 40 \\
$7-13$ & 30 & 20 \\
$14-20$ & 20 & \\
\cline { 2 - 3 } Potassium in the soil - ppm & & 60 \\
Until 30 & 40 & 50 \\
$30-60$ & 30 & 50 \\
$61-90$ & - &
\end{tabular}

Source: Manual De Adubação E Calagem Para O Estado Da Bahia (1989)

TABLE 3 - Total volume of irrigation per Yellow Passion Fruit plant (Passiflora edulis Sims f. flavicarpa Deg.) from the application of variable levels during the period of conduction of 180 days. Juazeiro-BA, 2014.

\begin{tabular}{cc}
\hline Treatment/levels & Applied volume in liters/plant \\
\hline $100 \%$ & 637.5 \\
$80 \%$ & 519.1 \\
$60 \%$ & 400.5 \\
$40 \%$ & 282.1 \\
$20 \%$ & 164.1 \\
\hline
\end{tabular}


TABLE 4- Chemical characteristics of the water of 'Sobradinho' lake used in the irrigation of the Yellow Passion Fruit plants (Passiflora edulis Sims f. flavicarpa Deg.) Juazeiro-BA, 2014.

\begin{tabular}{lc}
\hline Parameters & Values \\
\hline Total nitrogen $(\mathrm{mg} / \mathrm{L} \mathrm{N})$ & 0.39 \\
Total chlorides $\left(\mathrm{mg} / \mathrm{L} \mathrm{Cl}^{-}\right)$ & 3.87 \\
Total sulphate $\left(\mathrm{mg} / \mathrm{L} \mathrm{SO}_{4}^{2-}\right)$ & 0.001 \\
$\mathrm{EC}\left(\mathrm{dS} \mathrm{m}^{-1}\right)$ & 0.107 \\
\hline $\mathrm{pH}$ & 7.64 \\
Carbonates $\left(\mathrm{mg} \mathrm{CO}^{2-} / \mathrm{L}\right)$ & 0.0 \\
Bicarbonates $\left(\mathrm{mg} \mathrm{HCO}_{3}^{-} / \mathrm{L}\right)$ & 1.86 \\
Total calcium $\left(\mathrm{mg} \mathrm{Ca}^{2+} / \mathrm{L}\right)$ & 5.29 \\
\hline Total magnesium $\left(\mathrm{mg} \mathrm{Mg}^{2+} / \mathrm{L}\right)_{<0\}}$ & 1.95 \\
\hline Total sodium $\left(\mathrm{mg} \mathrm{Na}^{+} / \mathrm{L}\right)$ & 2.47 \\
\hline Total potassium $\left(\mathrm{mg} \mathrm{k}^{+} / \mathrm{L}\right)$ & 1.8 \\
Total dissolved solids at $180^{\circ} \mathrm{C}$ & 97.0 \\
Sodium Adsorption relation $(\mathrm{SAR})$ & \\
$($ mmolc L-1 & 0.071 \\
\hline
\end{tabular}

TABLE 5- Plant height (cm) of Yellow Passion Fruit (Passiflora edulis Sims f. flavicarpa Deg.) at 45 and 75 DAT cultivated in polyethylene bags and in conventional system, submitted to different irrigation levels. Juazeiro-BA. 2014.

\begin{tabular}{lccccc}
\hline Cultivation System & \multicolumn{5}{c}{ Irrigation Levels } \\
\hline \multirow{3}{*}{ Conventional } & $\mathbf{1 0 0} \mathbf{8 0}$ & $\mathbf{8 0} \mathbf{6 0}$ & $\mathbf{6 0} \%$ & $\mathbf{4 0} \%$ & $\mathbf{2 0} \%$ \\
\cline { 2 - 6 } In bags & $65.25 \mathrm{aA}$ & $44.25 \mathrm{bA}$ & $72.50 \mathrm{aA}$ & $53.75 \mathrm{aA}$ & $55.50 \mathrm{aA}$ \\
& $71.75 \mathrm{aA}$ & $92.50 \mathrm{aA}$ & $64.75 \mathrm{aA}$ & $63.25 \mathrm{aA}$ & $72.50 \mathrm{aA}$ \\
\cline { 2 - 6 } & $\mathrm{CV}(\%)=21.77$ & $\mathbf{7 5} \mathbf{D A T}$ \\
\cline { 2 - 6 } & $110.25 \mathrm{bA}$ & $78.00 \mathrm{bB}$ & $105.75 \mathrm{bA}$ & $96.25 \mathrm{aAB}$ & $115.50 \mathrm{aA}$ \\
\cline { 2 - 6 } In bags & $141.00 \mathrm{aB}$ & $186.00 \mathrm{aA}$ & $139.25 \mathrm{aB}$ & $93.00 \mathrm{aC}$ & $76.25 \mathrm{bC}$ \\
\hline \multicolumn{6}{c}{$\mathrm{CV}(\%)=15.18$} \\
\hline
\end{tabular}

Averages followed by the same lower case in columns and capital letters in line do not differ from each other by Tukey test at $5 \%$ probability of error. 
TABLE 6- Stem diameter (cm) of the Yellow Passion Fruit plant (Passiflora edulis Sims f. flavicarpa Deg.) at 45, 75 and 105 days after transplanting (DAT), cultivated in polyethylene bags and in conventional system, submitted to different irrigation levels, Juazeiro-BA, 2014.

\begin{tabular}{|c|c|c|c|c|c|}
\hline \multirow[t]{2}{*}{ Cultivation System } & \multicolumn{5}{|c|}{ Irrigation Levels } \\
\hline & $100 \%$ & $80 \%$ & $60 \%$ & $40 \%$ & $20 \%$ \\
\hline & & 45 DAT & & & \\
\hline Conventional & 8.75 & 7.50 & 9.75 & 8.00 & 7.75 \\
\hline \multirow[t]{3}{*}{ In bags } & 8.75 & 10.75 & 9.75 & 8.50 & 8.25 \\
\hline & $C V(\%)=15.18$ & & & & \\
\hline & & & 75 DAT & & \\
\hline Conventional & $12.00 \mathrm{aA}$ & $8.00 \mathrm{bB}$ & $10.75 \mathrm{aAB}$ & $9.00 \mathrm{aAB}$ & $10.50 \mathrm{aAB}$ \\
\hline \multirow[t]{3}{*}{ In bags } & $12.00 \mathrm{aA}$ & $13.50 \mathrm{aA}$ & $11.50 \mathrm{aAB}$ & $8.75 \mathrm{aB}$ & $11.00 \mathrm{aAB}$ \\
\hline & $\mathrm{CV}(\%)=15.18$ & & & & \\
\hline & & & 105 DAT & & \\
\hline Conventional & $17.50 \mathrm{aAB}$ & $20.50 \mathrm{aA}$ & $20.00 \mathrm{aA}$ & $14.75 \mathrm{aB}$ & $18.75 \mathrm{aA}$ \\
\hline In bags & $17.50 \mathrm{aAB}$ & 16.75 Bab & $19.50 \mathrm{aA}$ & $15.7 \mathrm{aB}$ & $17.25 \mathrm{aAB}$ \\
\hline
\end{tabular}

Averages followed by the same lower case in columns and capital letters in line do not differ from each other by Tukey test at $5 \%$ probability of error. No letters $=$ no significant $_{<0}$

TABLE 7 - Number of tertiary branches of Yellow Passion Fruit plants (Passiflora edulis Sims f. flavicarpa Deg.) at 105 days after transplanting (DAT), cultivated in polyethylene bags and in conventional system, submitted to different irrigation levels. Juazeiro-BA, 2014.

\begin{tabular}{lccccc}
\hline \multirow{2}{*}{ Cultivation System } & \multicolumn{5}{c}{ Irrigation Levels } \\
\cline { 2 - 6 } \multicolumn{1}{c}{ Conventional } & $100 \%$ & $80 \%$ & $60 \%$ & $40 \%$ & $20 \%$ \\
\hline In bags & $0.25 \mathrm{bB}$ & $0.00 \mathrm{bB}$ & $2.00 \mathrm{aAB}$ & $1.75 \mathrm{aB}$ & $4.00 \mathrm{aA}$ \\
\hline
\end{tabular}

$\mathrm{CV}(\%)=45.22$

Averages followed by the same lower case in columns and capital letters in line do not differ from each other by Tukey test at $5 \%$ probability of error.

TABLE 8- Number of floral buds (NFB) at 105 days and number of fruits (NF) and average weight of fruits (AWF) at 210 days after transplanting (DAT) of Yellow Passion Fruit plants (Passiflora edulis Sims f. Flavicarpa Deg.) cultivated in polyethylene bags and in conventional system. Juazeiro-BA, 2014.

\begin{tabular}{lccc}
\hline \multirow{2}{*}{ Cultivation System } & 105 DAT & \multicolumn{2}{c}{ 210 DAT } \\
\cline { 2 - 4 } & NFB & $19.75 \mathrm{~b}$ & AWF \\
\hline Conventional & $0.95 \mathrm{a}$ & $270.1 \mathrm{a}$ \\
In bags & $0.60 \mathrm{~b}$ & 32.94 & $209.9 \mathrm{~b}$ \\
CV $(\%)$ & 58.89 & 18.34 \\
\hline
\end{tabular}

Averages followed by the same letters in columns do not differ from each other by Tukey test at $5 \%$ probability of error. 
TABLE 9- Number of floral buds (NFB) at 105 days and number of fruits (NF) and average weight of fruits (AWF) at 210 days after transplanting (DAT) of Yellow Passion Fruit plants (Passiflora edulis Sims f. Flavicarpa Deg.) submitted to different irrigation levels. Juazeiro-BA, 2014.

\begin{tabular}{l|c|c|c}
\hline \multirow{2}{*}{ Irrigation Levels } & 105 DAT & \multicolumn{2}{|c}{ 210 DAT } \\
\cline { 2 - 4 } & NFB & NF & AWF \\
\hline $100 \%$ & $1.62 \mathrm{a}$ & $27.50 \mathrm{a}$ & $250.25 \mathrm{a}$ \\
$80 \%$ & $1.12 \mathrm{ab}$ & $27.62 \mathrm{a}$ & $217.12 \mathrm{a}$ \\
$60 \%$ & $0.62 \mathrm{bc}$ & $18.12 \mathrm{~b}$ & $215.62 \mathrm{a}$ \\
$40 \%$ & $0.25 \mathrm{c}$ & $17.62 \mathrm{~b}$ & $237.37 \mathrm{a}$ \\
$20 \%$ & $0.25 \mathrm{c}$ & $26.00 \mathrm{a}$ & $204.75 \mathrm{a}$ \\
\hline $\mathrm{CV}(\%)$ & 58.89 & 32.94 & 18.35 \\
\hline
\end{tabular}

Averages followed by the same letters in columns do not differ from each other by Tukey test at $5 \%$ probability of error.

TABLE 10 -Leaf area $\left(\mathrm{cm}^{2}\right)$ in Yellow Passion Fruit plants (Passiflora edulis Sims f. flavicarpa Deg.) cultivated in polyethylene bags and in conventional system under different irrigation levels, Juazeiro-BA, 2014.

\begin{tabular}{cccc}
\hline \multicolumn{2}{c}{ Cultivation in bags } & \multicolumn{2}{c}{ Conventional } \\
Irrigation Levels & Averages $\left(\mathbf{c m}^{2}\right)$ & Irrigation Levels & Averages $\left(\mathbf{c m}^{2}\right)$ \\
\hline $100 \%$ & 499.5 & $100 \%$ & 549.1 \\
$80 \%$ & 444.1 & $80 \%$ & 533.1 \\
$60 \%$ & 436.5 & $60 \%$ & 340.4 \\
$40 \%$ & 386.5 & $40 \%$ & 412.2 \\
$20 \%$ & 3644 & $20 \%$ & 282.8 \\
\hline Average & 426.2 & & 423.5 \\
\hline
\end{tabular}

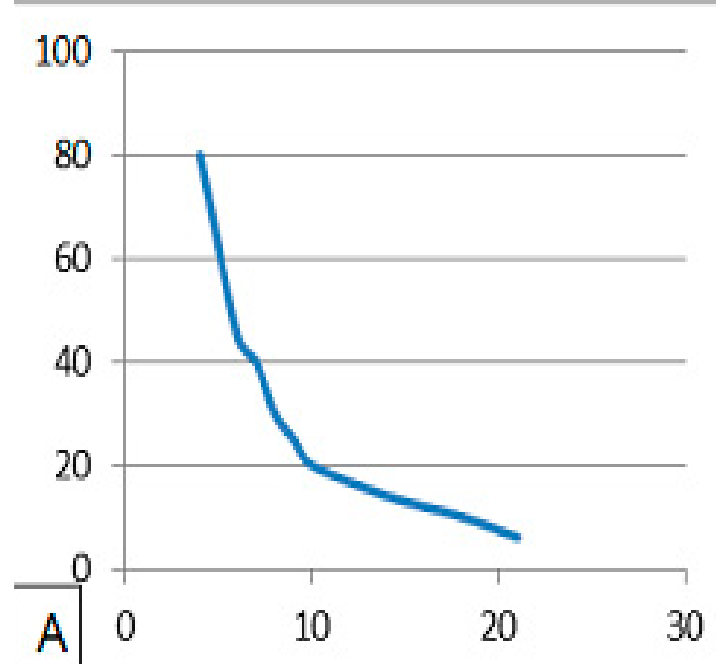

water in the soil $\mathrm{cm}^{3} / \mathrm{cm}^{3}$

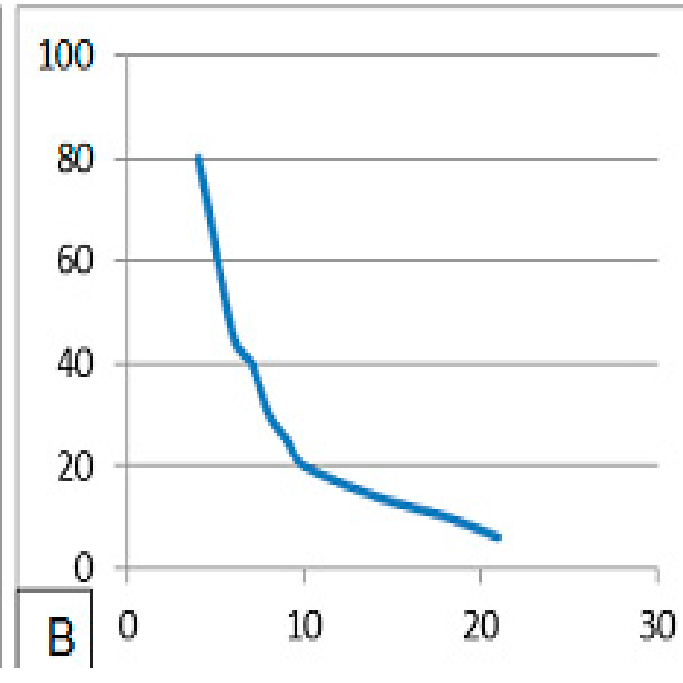

water in the soil $\mathrm{cm}^{3} / \mathrm{cm}^{3}$

FIGURE 1- Retention curves of water in the soil: figure A, soil of the conventional system; figure B, in polyethylene bags. Juazeiro-BA, 2014. 


\section{CONCLUSION}

The highest agronomic performance of the Yellow Passion Fruit occurred when it was cultivated in polyethylene bags with irrigation levels of $80 \%$.

\section{REFERENCES}

ARAÚJO, H.F.; COSTA, R.N.T.; CRISÓSTOMO, J.R.; SAUNDERS, L.C.U.; MOREIRA, O.C.; ARAÚJO, A.B.M.M. Produtividade e análise de indicadores técnicos do Maracujazeiro-amarelo irrigado em diferentes horários. Revista Brasileira de Engenharia Agrícola e Ambiental, Campina Grande, v.16, n.2, p.159-164, 2012.

ATAÍDE, E.M.; OLIVEIRA, J.C.; RUGGIERO, C. Florescimento e frutificação do maracujazeiro silvestre Passiflora setacea D. C. cultivado em Jaboticabal, SP. Revista Brasileira de Fruticultura, Jaboticabal, v.34, n.2, p.377-381, 2012.

BANDEIRA, G.R.L.; QUEIROZ, S.O.P; ARAGÃO, C.A.; COSTA, N.D.; SANTOS, C.A.F. Desempenho agronômico de cultivares de cebola sob diferentes manejos de irrigação no submédio São Francisco. Irriga, Botucatu, v.18, n.1, p.73- 84, 2013.

BERNARDO, S. Manual de irrigação. 8.ed. Viçosa: Ed. UFV, 2009. 625p.

CARVALHO, J.A.; KOETZ, M.; SOUSA, A.M.G.; SOUZA, K.J.S.; Desenvolvimento e produtividade do Maracujazeiro-amarelo irrigado sob diferentes lâminas de irrigação em ambiente protegido e natural. Engenharia Agrícola, Jaboticabal, v.30, n.5, p.862874, 2010.

CAVICHIOLI, J. C.; CORRÊA, L. S.; BOLIANI, A. C.; SANTOS, P. C. Desenvolvimento e produtividade do Maracujazeiro-amarelo enxertado em três portaenxertos, Revista Brasileira de Fruticultura, Jaboticabal, v.33, n.2, p.558-566, 2011 a.

CAVICHIOLI, J.C.; CORREAA, L.S.; GARCIA, M.J.M.; FISCHER, I. H. Desenvolvimento, produtividade e sobrevivência de Maracujazeiroamarelo enxertado e cultivado em área com histórico de morte prematura de plantas, Revista Brasileira de Fruticultura, Jaboticabal, v.33, n.2, p.567-574, $2011 b$
CAVICHIOLI, J.C.; KASAI, F.S.; NASSER, M.D.; Produtividade e características físicas de frutos de Passiflora edulis enxertado sobre Passiflora gibertil em diferentes espaçamentos de plantio. Revista Brasileira de Fruticultura, Jaboticabal, v.36, n.1, p.243-247, 2014.

CAZARIN, C.B.B.; SILVA, J.K.; COLOMEU, T.C.; ZOLLNER, R.L.; MARÓSTICA JUNIOR, M.R. Capacidade antioxidante e composição química da casca de maracujá (Passiflora edulis). Ciência Rural, Santa Maria, v.44, n.9, p.1699-1704, 2014.

CORDEIRO, C. G. Qualidade de água para fins de irrigação (conceitos básicos e práticas). Petrolina: Embrapa Semiárido, 2001. 32 p. (Documentos, 167).

EMBRAPA. Registro de observaçoes meteorológicas. Petrolina: Embrapa Semiárido, 2012. Disponível em: $<$ http://www.cpatsa.embrapa. br: 8080/serviços/dadosmet/ceb-anual.html $>$. Acesso em: 11 jun. 2013.

HAFLE, O.M.; RAMOS, J.D.; LIMA, L.C.O.; FERREIRA, E.A.; MELO, P.C. Produtividade e qualidade de frutos de Maracujazeiro-amarelo submetido a poda de ramos produtivos. Revista Brasileira de Fruticultura, Jaboticabal, v.31, n.3, p. $763-770,2009$.

IBGE - Instituto Brasileiro de Geografia e Estatística. 2012. Disponível em: $<$ http://www.sidra.ibge.gov. $\mathrm{br} / \mathrm{bda} /$ agric/default.asp? $\mathrm{t}=4 \& \mathrm{z}=\mathrm{t} \& \mathrm{o}=11 \& \mathrm{u} 1=1 \&$

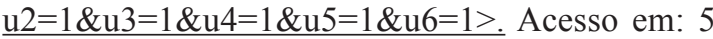
dez. 2012.

LAREDO, R.R, Tamanho da muda na produção e qualidade dos frutos de maracujazeiro cv. Redondo amarelo. 2013. 70 f. Dissertação (Agronomia/Fitotecnia) -Universidade Federal de Lavras, Lavras, 2013.

MANUAL de adubação e calagem para o estado da Bahia. 2.ed. Salvador: CEPLAC/EMATERBA/ EMBRAPA/EPABA/NITROFERTIL, 1989. 175p.

MELETTI, L.M.M. Avanços da cultura do maracujá no Brasil. Revista Brasileira de Fruticultura, Jaboticabal, p. 83-91, 2011. Volume especial. 
NASSER, M.D.; CAVICHIOLI, J.C.; KASAI, F.S.; VITORINO, R. Desenvolvimento de Maracujazeiroamarelo enxertado sobre maracujazeiro-doce em diferentes espaçamentos de plantio. Revista Brasileira de Fruticultura, Jaboticabal, p.638-642, 2011. Volume especial

SANTOS, J.C.B.; SOUZA JÚNIOR, V.S.; CORRÊA, M.M.; RIBEIRO, M.R.;ALMEIDA, M.C.; BORGES, L.E.P. Caracterização de neossolos regolíticos da região semiárida do Estado de Pernambuco. Revista Brasileira de Ciências do Solo, Viçosa, MG, v.36, n.3, p.683-695, 2012
SUASSUNA, J.F. Desenvolvimento e eficiência fotoquímica em mudas de híbrido de maracujazeiro sob lâminas de água, Bioscience Journal, Uberlândia, v. 26, n.4, p.566-571, 2010.

TAIZ, L.; ZEIGER, E. Fisiologia vegetal. 5. ed. Porto Alegre: Artmed, 2012. 954p.

ZERAIK, M.L.; PEREIRA, C.A.M.; ZUIN, V.G.; YARIWAKE, J.H. Maracujá: um alimento funcional? Revista Brasileira de Farmacognosia, Curitiba, v.20, n.3, p.459-471, 2010. 